\title{
An incidentally detected pelvic kidney in a patient of cervical carcinoma imaged for radiotherapy planning
}

\author{
Siddanna R Palled, ${ }_{1}^{1}$ Swaroop Revannasiddaiah, ${ }^{2}$ Vijetha Jayakumar, ${ }^{2}$ Eranna R Palled ${ }^{3}$
}

${ }^{1}$ Department of Radiation Oncology, Kidwai Memorial Institute of Oncology, Bengaluru, Karnataka, India ${ }^{2}$ Department of Radiation Oncology, HealthCare Global -Bangalore Institute of Oncology, Bengaluru, Karnataka, India

Department of Radiodiagnosis, Belgaum Institute of Medical Sciences, Belgaum, Karnataka, India

Correspondence to Dr Swaroop Revannasiddaiah, swarooptheone@gmail.com

\section{DESCRIPTION}

A patient diagnosed with an International Federation of Gynaecology and Obstetrics Stage- $\mathrm{IB}_{2}$ cervical carcinoma was referred to us for radiation-based treatment, given the evidence for equivalence of surgical and radiotherapeutic managements. ${ }^{1}$ In preparation for standard chemoradiotherapy (a plan of three-dimensional conformal

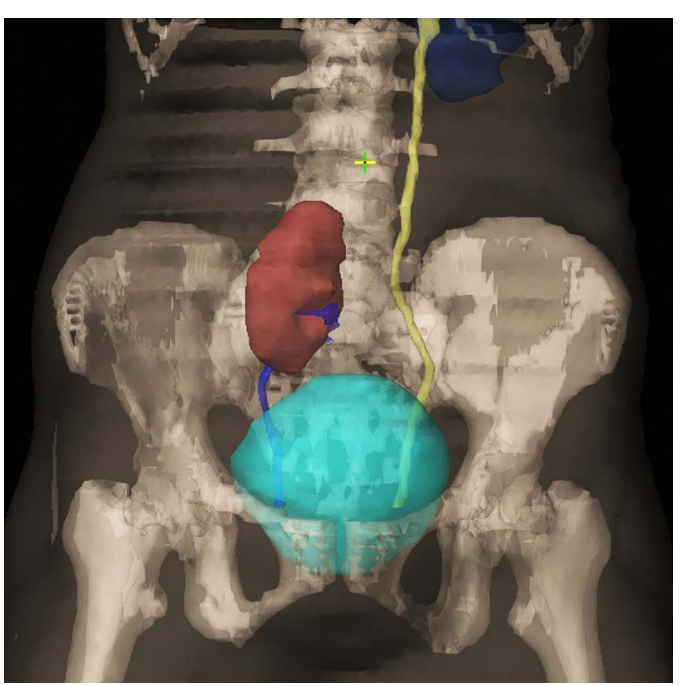

Figure 1 Volumetric reconstruction of the pelvic CT scan demonstrating the ectopic location of the right kidney (maroon). Also seen are the left-kidney (dark blue) and the urinary bladder (cyan). radiotherapy with concurrent cisplatin chemotherapy followed by brachytherapy), the patient underwent a CT scan as part of the RT planning process. Surprisingly, the presence of an ectopic pelvic kidney was noted (figure 1). Noting the normal excretion of contrast in the ipsilateral ureter, the pelvic kidney was functional in all probability (figure 2)

Given the early stage (IB2), we had the luxury to cancel RT and to opt for radical hysterectomy. The standard RT portals for cervical carcinoma targets the disease, as well as the pelvic-lymphatics including the common, internal and external iliac lymph nodes, along with the obturator and presacral lymph nodes (figure 3 ). Thus, the use of pelvic external-beam RT (to a dose of 45-50 Gy) would have easily exceeded the tolerance limits of the pelvic kidney (estimated as 28 Gy for a 50\% risk of complications at 5 years). ${ }^{2}$

The pelvic kidney results from the failure in normal ascent of a kidney, and is known to have an incidence of one in 2000-3000 persons. The affected patients are usually asymptomatic, with the involved kidney being functionally normal. ${ }^{3}$

In the possible scenario wherein a patient with a pelvic kidney presents with a cervical cancer staged beyond IIA, the use of RT becomes mandatory. In such situations, the use of intensity-modulated radiotherapy would be able to deliver adequate doses of radiation to the primary disease and the nodal areas, while at the same time sparing the pelvic kidney from overdose. ${ }^{4}$

\begin{tabular}{l}
\hline To cite: Palled SR, \\
Revannasiddaiah S, \\
Jayakumar V, et al. BMJ \\
Case Reports Published \\
online: 2 January 2013 \\
doi:10.1136/bcr-2012- \\
007921 \\
\hline
\end{tabular}

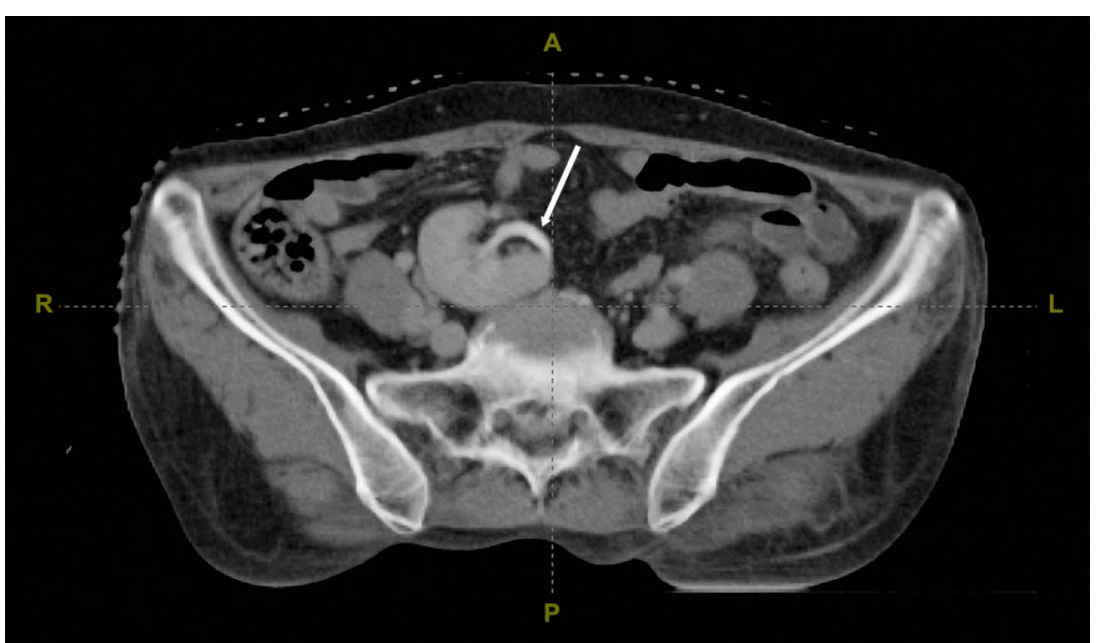

Figure 2 Axial CT slice demonstrating the location of the right-kidney within the pelvic cavity. The functionally intact kidney is shown to excrete contrast into the ipsilateral ureter (white arrow). 


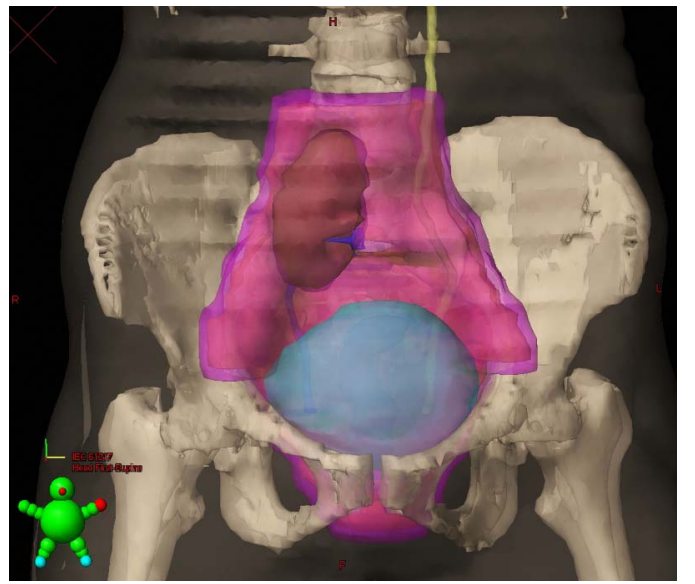

Figure 3 The right kidney is shown in relation to the clinical target volume (pink shaded volume) which includes the primary disease and the pelvic lymph nodes.

\section{Competing interests None.}

\section{Patient consent Obtained.}

Provenance and peer review Not commissioned; externally peer reviewed.

\section{REFERENCES}

1 Landoni F, Maneo A, Colombo A, et al. Randomised study of radical surgery versus radiotherapy for stage Ib-lla cervical cancer. Lancet 1997;350:535-40.

2 Emami B, Lyman J, Brown A, et al. Tolerance of normal tissue to therapeutic irradiation. Int I Radiat Oncol Biol Phys 1991;21:109-22.

3 Cinman NM, Okeke Z, Smith AD. Pelvic kidney: associated diseases and treatment. J Endourol 2007;21:836-42.

4 Ramamurthy R, Muthusamy V, Hussain SA. Approach to carcinoma cervix with pelvic kidney. Indian J Surg Oncol 2010;1:323-7.

\section{Learning points}

- The non-use of sectional imaging prior to the initiation of radiotherapy may render the clinician oblivious to the presence of a pelvic kidney.

- The treatment of early-stage carcinoma of the cervix in the presence of a pelvic kidney is better attempted with surgery than with radiotherapy.

- For locally advanced carcinoma of the cervix, where the use of radiotherapy is warranted, it is better attempted with intensity-modulated radiotherapy, which holds the potential to spare the pelvic kidney while at the same time delivering desired doses of radiation to the target primary and nodal areas.

Copyright 2013 BMJ Publishing Group. All rights reserved. For permission to reuse any of this content visit

http://group.bmj.com/group/rights-licensing/permissions.

BMJ Case Report Fellows may re-use this article for personal use and teaching without any further permission.

Become a Fellow of BMJ Case Reports today and you can:

- Submit as many cases as you like

- Enjoy fast sympathetic peer review and rapid publication of accepted articles

- Access all the published articles

- Re-use any of the published material for personal use and teaching without further permission

For information on Institutional Fellowships contact consortiasales@bmjgroup.com

Visit casereports.bmj.com for more articles like this and to become a Fellow 